\title{
STUDI USAHATANI KEDELAI MELALUI PENDEKATAN SISTEM AGRIBISNIS DI KECAMATAN BERBAK KABUPATEN TANJUNG JABUNG TIMUR
}

\section{STUDY ON SOYBEAN AN APPROACH FARMING SYSTEM AGRIBUSINESS IN DISTRICT BERBAK REGENCY EAST CAPE JABUNG JAMBI PROVINCE}

\author{
Rono $^{1}$, Sa'ad Murdy ${ }^{2}$ dan Saidin Nainggolan ${ }^{2}$
}

1) Alumni Program Studi Agribisnis Fakultas Pertanian Universitas Jambi,

2) Dosen Program Studi Agribisnis Fakultas Pertanian Universitas Jambi

Email: $\underline{\text { rono.ijtihad@yahoo.co.id }}$

\begin{abstract}
ABSTRAK
Penelitian ini bertujuan untuk mengetahui kondisi dan kinerja pada masingmasing sub sistem yang membangun sistem agribisnis kedelai di Kecamatan Berbak Kabupaten Tanjung Jabung Timur, serta mengetahui tingkat pendapatan yang diperoleh petani kedelai didaerah penelitian. Penelitian ini dilakukan di dua Desa yang ada di Kecamatan Berbak dengan menggunakan 58 petani sampel, yang terdiri dari 36 petani di Kelurahan Simpang dan 22 petani di Desa Rantau Makmur. Hasil studi terhadap Sistem agribisnis kedelai di daerah penelitian menunjukan kondisi cukup baik, ditandai dengan masing-masing sub sistem agribisnis telahmenjalankan kegiatan agribisnis sesuai fungsi dan peranannya. Selain itu kinerja agribisnis kedelai di daerah penelitian juga berjalan cukup baik dan terdapat keterkaitan yang cukup erat antara satu sub sistem dengan sub sistem lain, ditandai dengan masing masing pelaku sub sistem sudah menjalankan peranan dan fungsinya dengan baik serta mendapat keuntungan dan manfaat dari kegiatan usahanya. Serta dari hasil analisis pendapatan usahatani kedelai di daerah penelitian menunjukan bahwa usahatani kedelai yang dilakukan petani memberikan pendapatan yang cukup tinggi dimana memiliki R/C sebesar 1,84 .
\end{abstract}

Kata kunci: Usahatani Kedelai, Sistem Agribisnis, Pendapatan

\section{ABSTRACT}

This research aims to determine the condition and performance of each subsystem that builds soybean agribusiness system in the District Berbak on the Regenci of East Cape Jabung, as well as determine the level ofincome earned soybean farmer research area. This research was conducted in two villages in the District Berbak by using 58 sample farmers, consisting of 36 farmers in the village of Simpang and 22 farmers in the village of Rantau Makmur. The results of studies on soy agribusiness system in the study area showed fairly good condition, characterized by each sub-system agribusiness activities appropriate to the function and role of soy agribusiness can run the system as a whole. In addition, soy agribusiness performance in the study areais also quite good and there isa fairly close relationship between the sub-systems with other sub-systems, each characterized by a sub-system actors have roles and functions run smoothly and to benefit and the benefit of their business activities. As well as fromthe results of the analysis of soybean farming income in the study area showed that soybean farmers do provide a high enough income which has of $R / C$ of 1.84 .

Keywords: Soybean Farming, Agribusiness Systems, Revenue. 


\section{PENDAHULUAN}

Pembangunan pertanian adalah upaya meningkatkan peran sektor pertanian dalam arti luas dalam pembangunan nasional. Sejalan dengan pemikiran (Saragih, 2001), pembangunan bukan hanya upaya peningkatan volume produksi pertaniannya, namun lebih menekankan pada peningkatan pendapatan petani dan perubahan perilaku petani dari sub sistem ke komersial sehingga dapat mewujudkan ketangguhan sektor pertanian secara menyeluruh

Provinsi Jambi memiliki Kabupaten-Kabupaten yang banyak memproduksi kedelai yang kualitasnya jauh lebih baik dari kedelai impor yang banyak di jumpai akan tetapi konsumsi kedelai di Provinsi Jambi lebih besar dari produksi yang dihasilkan, hal ini ditunjukkan bahwa produksi kedelai (ton) dari tahun 2009-2011 selalu mengalami penurunan, sedangkan konsumsi penduduk atas kedelai (ton) terus mengalami peningkatan. Salah satu sentra produksi tanaman kedelai di Provinsi Jambi adalah Kabupaten Tanjung Jabung Timur. Kabupaten Tanjung Jabung Timur menduduki tingkat pertama dalam produksi kedelai yaitu sebesar 1.899 Ton dengan luas panen $1.444 \mathrm{Ha}$ dengan produktivitas sebesar $13.15 \mathrm{Kw} / \mathrm{Ha}$ (Dinas Pertanian dan Tanaman Pangan Tanjung Jabung Timur Tahun 2011) lebih tinggi produktifitasnya dibandingkan produktivitas provinsi yang hanya $12.54 \mathrm{Kw} / \mathrm{Ha}$ (Dinas Pertanian dan Tanaman Pangan Tanjung Jabung Timur Tahun 2012).

Salah satu sentra produksi tanaman kedelai di Kabupaten Tanjung Jabung Timur adalah di Kecamatan Berbak yang mempunyai areal luas panen usahatani kedelai yang relatif luas dibandingkan dengan kecamatan lain yang ada di Kabupaten Tanjung Jabung Timur dengan luas panen sebesar $729 \mathrm{Ha}$ dengan produksi sebanyak 1.100 Ton dan tingkat produktivitas sebesar $13,89 \mathrm{Kw} / \mathrm{Ha}$.

Dilihat dari luas panen, produksi dan produktivitas kedelai baik di Kabupaten maupun Kecamatan, produktivitas kedelai di Kabupaten Tanjung Jabung Timur masih diperlukan peningkatan jika dibandingkan dengan jumlah lahan yang dimiliki yaitu relatif luas. Salah satu upaya yang harus dilakukan adalah melakukan peningkatan produksi dengan cara menerapkan sistem agribisnis pada usahatani kedelai di Kabupaten Tanjung Jabung Timur. Pengembangan usahatani kedelai dengan berorientasi agribisnis akan dapat memberikan nilai tambah bagi petani apabiala dilakukan secara profesional yaitu mampu memproduksi, mengelola hasil produksi dan memasarkan hasilnya dengan baik serta adanya bantuan pihak lain yang berperan dalam penyediaan dan penyaluran input, lembaga terkait dan pemerintah.

Penerapan sistem agribisnis harus dilakukan secara sinergis dan saling menguatkan antar sub sistem untuk mendukung tercapainya produksi yang optimal. Kelengkapan sistem agribisnis merupakan salah satu indikator keberhasilan di sektor pertanian karena dapat menggambarkan besarnya nilai tambah produk dengan kata lain, pengembangan sistem agribisnis komoditas salah satu upaya untuk meningkatkan nilai tambah produk. Indikator tersebut akan memberikan gambaran atau perbandingan dari kegiatan sistem agribisnis yang biasa dilakukan oleh petani kedelai di Kecamatan Berbak Kabupaten Tanjung Jabung Timur.

Berdasarkan uraian di atas maka penulis tertarik untuk melakukan penelitian dengan judul "Studi Usahatani Kedelai Melalui Pendekatan sistem Agribisnis di Kecamaatan Berbak Kabupaten Tanjung Jabung Timur".

Beberapa permasalahan yang akan dibahas dalam penelitian ini adalah bagaimana kondisi dan diskripsi setiap sub sistem agribisnis usahatani kedelai serta bagaimana kinerja antar sub sistem agribisnis usahatani kedelai di Kecamatan Berbak Kabupaten Tanjung Jabung Timur. Adapun tujuan penelitian ini adalah untuk 
mengetahui kondisi dan deskripsi setiap sub sistem agribisnis usahatani kedelai dan untuk mengetahui kinerja antar sub sistem agribisnis usahatani kedelai di Kecamatan Berbak Kabupaten Tanjung Jabung Timur.

\section{METODE PENELITIAN}

Penelitian ini dilaksanakan di Kecamatan Berbak Kabupaten Tanjung Jabung Timur yaitu di Desa Kelurahan Simpang dan Desa Rantau makmur dengan pertimbangan bahwa daerah ini merupakan daerah yang mengusahakan usahatani kedelai dan merupakan daerah penghasil kedelai tertinggi. Penelitian ini akan difokuskan untuk mengetahui meliputi aktivitas yang dilakukan oleh para pelaku agribisnis usahatani kedelai pada masing-masing sub sistem serta kinerja antar sub sistem itu sendiri dalam suatu sistem agribisnis yang terdiri dari sub sistem agro-input, sub sistem usahatani dan sub sistem pemasaran serta lembaga penunjang yang mendukung berlangsungnya kegiatan agribisnis didaerah penelitian.

Metode pengambilan sampel dilakukan dengan metode acak sederhana (Simple Random Sampling) dengan menggunakan tabel acak, berdasarkan status petani yaitu petani di Kelurahan Simpang dan petani di Desa Rantau Makmur. Jumlah populasi petani sampel yang digunakan dalam penelitian ini sebanyak 58 petani yang ditetapkan secara sengaja dengan pembagian secara proporsional yaitu 36 petani kedelai untukKelurahan Simpang dan 30 petani kedelai untukDesa Rantau makmur.

Metode analisis data yang digunakan dalam penelitian ini adalah deskriptif. Menurut Nazir (2003) analisis deskriptif adalah suatu metode meneliti status kelompok manusia, suatu objek, suatu set kondisi, suatu sistem pemikiran ataupun suatu kelas peristiwa pada masa sekarang dengan tujuan untuk membuat deskriptif, gambaran atau lukisan secara sistematik, faktual dan akurat mengenai fakta-fakta, sifat-sifat serta hubungan antar fenomena yang diselidiki. Dalam upaya memperkaya data dan lebih memahami fenomena sosial yang diteliti, terdapat upaya untuk menambah informasi kualitatif pada data kuantitatif (Singarimbun dan Sofyan, 1998).

Adapun kajian yang dilakukan dalam penelitian ini adalah :

a) Identifikasi terhadap sistem agribisnis usahatani kedelai.

1. Sub sistem hulu

2. Sub sistem usahatani

3. Sub sistem hilir

4. Sub sistem lembaga penunjang

b) Identifikasi terhadap kinerja antar sub sistem pada kegiatan agribisnis usahatani kedelai dimulai dari kegiatan hulu sampai hilir dan melihat sejauh mana penerapan agribisnis dapat meningkatkan pendapatan petani. Untuk menghitung penerimaan yang diperoleh petani adalah dengan cara mengalikan jumlah komoditi dengan harga jual.

$\mathrm{TR}=\mathrm{P} . \mathrm{Q}$

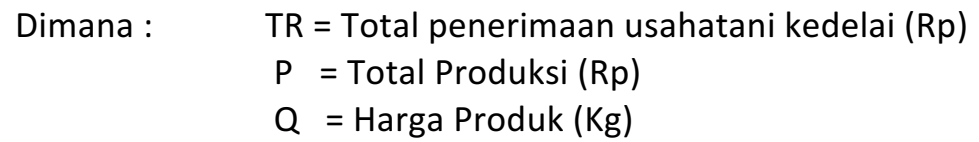

Untuk menghitung pendapatan/ keuntungan yang diperolah petani di lokasi penelitian yaitu dengan cara mengurangi total penerimaan dengan total biaya. Selisih dari nilai produksi (penerimaan) dengan biaya-biaya yang dikeluarkan tersebut dikatakan sebagai pendapatan usahatani. Secara sistematis dapat ditulis sebagai berikut: 


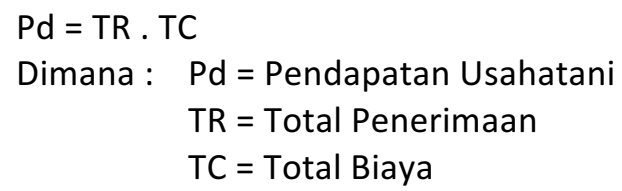

\section{HASIL DAN PEMBAHASAN}

\section{Karakteristik Petani}

Dari hasil penelitian terlihat bahwa rata-rata petani kedelai di daerah penelitian berada pada kelompok umur 34 - 39 tahun, pada usahatani kedelaidi daerah penelitian rata-rata petani berpengalaman usahatani $8-10$ tahun dengan besarnya koefisien variasi 37,93 \% dimana secara keseluruhan rata-rata petani di daerah penelitian menempuh tingkat pendidikan setara SD ( 3 tahun). Dari hasil penelitian juga terlihat bahwa rata-rata jumlah anggota keluarga petani sampel $4-5$ orang dengan besarnya koefisien variasi $69,96 \%$.

Usahatani kedelai di daerah penelitian dilakukan sekali dalam setahun, masalah yang sering dihadapi petani di daerah penelitian yaitu pengaruh iklim dan ketinggian tempat hanya 1-5 meter diatas permukaan laut sehingga sering terjadi banjir, hal ini mengakibatkan petani kurang maksimal untuk dapat melakukan kegiatan budidaya usahatani kedelainya. Kegiatan budidaya yang dilakukan petani dalam usahatani kedelai di mulai dari pengolahan lahan, persemaian, penanaman, penyulaman, pemupukan, penyiangan, tashapen, panen dan pasca panen.

\section{Sistem agribisnis Usahatani Kedelai}

Sub sistem hulu/input ini sangatlah penting peranannya dalam sistem agribisnis, karena kegiatan ini adalah pengadaan sarana produksi yang akan berpengaruh terhadap besar kecilnya jumlah produksi yang dihasilkan oleh sub sistem usahatani sehingga dalam kegiatannya sub sistem ini harus dapat memenuhi kebutuhan proses produksi subsistem usahatani. Dari hasil penelitian bahwa penggunaan benih kedelai oleh petani didaerah penelitian tertinggi pada selang 34 - $47 \mathrm{Kg}$ yaitu sebanyak 32 orang petani atau sebesar 55,17 persen. Untuk penggunaan pupuk urea dan pupuk phonska pada usahatani kedelai di daerah penelitian terbanyak pada rentang 25-50 Kg sebanyak 53,45 persen dan 46,55 persen, tetapi keadaan berbeda terjadi pada penggunaan pupuk SP36 dimana sebanyak 46,55 persen atau sebanyak 27 petani tidak menggunakan pupuk SP-36. Rata-rata penggunaan pupuk urea didaerah penelitian berkisar $62,32 \mathrm{Kg} / \mathrm{ha}$ Penggunaan benih kedelai didaerah penelitian disesuaikan dengan luas lahan yang dimiliki petani, dimana kebutuhan benih perhektarnya yaitu sebanyak $40 \mathrm{Kg}$. Pupuk yang dibeli oleh petani merupakan pupuk subsidi dari pemerintah yang pembeliannya disesuaikan dengan penggunaan lahan yang ada. Harga pupuk urea di daerah penelitian adalah Rp 112.000/ karung dengan kapasitas karung $50 \mathrm{Kg}$. Sedangkan untuk harga subsidi pupuk phonska dan SP-36 yaitu sebesar Rp 115.000/karung dengan kapasitas karung $50 \mathrm{Kg}$. Sedangkan untuk penggunaan obat-obatan dalam usahatani kedelai di daerah penelitian terdapat tiga jenis obat-obatan yaitu Bio-Up, Bio-Kron dan Decis dengan persentase penggunaan terbesar pada penggunaan Bio-Up yaitu 5 sampai 9 liter dengan persentase 67,24 persen atau sebanyak 39 petani dan pada penggunaan BioKron yaitu sebanyak 1 sampai 3 liter dengan persentase 53,45 persen. Sedangkan untuk penggunaan decis yaitu sebanyak 0,2 sampai 0,5 liter dengan persentase 55,18 persen dengan jumlah petani yang menggunakan yaitu sebanyak 32 petani. Penggunaan obatobatan dalam berusahatani kedelai akan memberikan beberapa keuntunagan untuk 
petani diantaranya dapat menghemat waktu kerja dan dapat menghemat tenaga kerja saat persiapan lahan dan penyiangan.

Sub sistem usahatani adalah suatu kegiatan yang dilakukan oleh petani untuk mengelola input produksi supaya menghasilkan produksi yang optimal sehingga bisa meningkatkan pendapatan yang dihasilkan oleh petani. Adapun total penggunaan tenaga kerja dalam usahatani kedelai di daerah penelitian adalah sebanyak 62 HOK dimana tenaga kerja dalam keluarga sebanyak 28 HOK dan luar keluarga sebanyak 35 HOK. Selain itu tabel diatas jga menunjukan bahwa total penggunaan tenaga kerja dalam usahatani kedelai di daerah penelitian dengan penggunaan tenaga kerja terbanyak untuk pemeliharaan yaitu 12 HOK dari dalam keluarga dan sebanyak 10 HOK dari luar keluarga. Penggunaan tenaga kerja terbanyak dalam pemeliharaan ini digunakan untuk beberapa kegiatan pemeliharaan diantaranya penyiangan, pemupukan dan pengendalian hama penyakit. Tenaga kerja luar keluarga lebih banyak digunakan untuk pekerjaan penanaman, pemanenan dan pengangkutan. Sedangkan tenaga kerja dalam keluarga disamping ikut bekerja dalam proses tanam maupun pemanenan juga bekerja pada saat pemeliharaan yaitu penyiangan pemupukan dan pengendalian hama penyakit.

Jumlah penggunaan tenaga kerja didaerah penelitian yaitu sebanyak $62 \mathrm{HOK}$ ini masih tergolong rendah apabila dibandingkan dengan penelitian Plantus (2008) yang menyebutkan bahwa jumlah tenaga kerja untuk budidaya kedelai dengan pola monokutur memerlukan 150 HOK. Rendahnya penggunaan tenaga kerja di daerah penelitian karena petani memiliki lahan dalam satu hamparan sehingga penggunaan tenaga kerja lebih efektif dan efesien. Selain itu upah tenaga kerja juga mahal yaitu Rp 60.000 ,- per hari sehingga tenga kerja dalam keluarga lebih menguntungkan jika bekerja pada orang lain.Dari hasil penelitian terhadap petani kedelai di daerah penelitian, di peroleh rata-rata produksi yang dihasilkan per petani adalah $1.605,43 \mathrm{Kg}$, sedangkan rata-rata produksi per hektarnya adalah $1.349,49 \mathrm{Kg}$. sedangkan produktivitas hasil produksi usahatani kedelai di daerah penelitian adalah sebesar 13,49 Kw/Ha.

Komponen pengolahan hasil pertanian menjadi penting sejalan dengan yang dikatakan oleh Nur dan Sinaga (1995) bahwa kegiatan pasca panen (pengolahan) perlu dilakukan di tujukan untuk meningkatkan nilai tambah dari komoditas tersebut, memperkecil tingkat kerusakan atau kehilangan hasil, meningkatnya daya simpan dan daya guna, meningkatnya kualitas/mutu hasil panen, meningkatkan penyerapan tenaga kerja, meningkatkan keterampilan produsen, serta meningkatkan harga jual dan pendapatan produsen/ petani. Biji kedelai yang sudah dijemur dengan kadar air 13-14\% kemudian digiling dengan menggunakan treher yng disediakan oleh kelompok tani. Setiap petani yang menggunakan jasa kelompok tani harus membayar biaya atau sewa sebesar $6 \%$ dari jumlah kedelai yang dihasilkan.Biaya tersebut digunakan untuk membayaar upah tenaga kerja, membeli minyak dan perawatan. Biji kedelai kemudian di sortir untuk memisahkan biji kedelai yang baik dengan yang buruk.Biji kedelai kemudian di beri perlakuan seperti pengemasan yaitu dimasukan kedalam karung dan siap untuk dijual.Petani di daerah penelitian umumnya menjual hasil panen kedelai ke pedagang pengumpul karena pedagang pengumpul yang langsung mendatangi rumah atau lahan kedelai petani untuk membeli hasil kedelai.Kemudian pedagang pengumpul menjual kedelai ke pedagang grosis, ke pasar Jambi, dan ke pengrajin tahu. Tingkat harga jual petani kedelai di daerah penelitian tidak terlalu berfluktuasi asalkan kualitas yang dihasilkan bisa sesuai dengan keinginan pelaku pemasaran selanjutnya, dimana kisaran harga pada saat musim panen kedelai yaitu sebesar $\mathrm{Rp} \mathrm{7.000/Kg}$ dan dengan harga jual pedagang pengumpul yaitu sebesar $\mathrm{Rp} 8.000 / \mathrm{Kg}$, adapun margin pemasaran pedagang pengumpul adalah sebesar $\mathrm{Rp} 1.000 / \mathrm{Kg}$. 
Lembaga penunjang agribisnis memiliki keterkaitan terhadap suatu sistem agribisnis secara keseluruhan. Hasil penelitian ini memperlihatkan bahwa keterkaitan antara lembaga penunjang dengan sistem agribisnis kedelai di daerah penelitian memiliki keterkaitan yang erat karena keberadaan lembaga penunjang ini akan sangat membantu para pelaku agribisnis pada setiap sub sistem dalam menjalankan peran dan fungsinya masing-masing. Peranan lembaga penunjang sangat diperlukan oleh pelaku agribisnis terutama petani sehingga akan menunjang keberhasilan agribisnis kedelai di daerah penelitian. Lembaga penunjang yang ada di derah penelitian yaitu kelompok tani, Gapoktan, Balai penyuluhan serta pemerintah.

\section{Keterkaitan Antar Sub Sistem dalam Sistem Agribisnis Kedelai}

Keterkaitan antar sub sistem hulu dengan sub sistem pertanian primer dapat dilihat dari hubungan kegiatan penyediaan agro-input dengan kegiatan usahatani/produksi. Terdapat keterkaitan erat yang dapat memberikan manfaat dan keuntungan pada masing-masing pelaku sub sistem, baik pada kegiatan maupun pelaku bisnis dari masing-masing sub sistem. Adapun persentase keterkaitan sub sistem pertanian primer dengan sub sistem hulu adalah $98 \%$. Keterkaitan tersebut dapat dilihat pada aktivitas para pelaku penyediaan input yang meliputi Gapoktan, kios pedagang desa dan pandai besi yang berperan dalam penyediaan sarana produksi seperti pupuk, pestisida dan alat-alat pertanian yang dibutuhkan petani dalam berusahatani kedelai.Adapun jumlah kios yang ada di kecamatan berbak adalah sebanyak 5 kios yang menyediakan sarana produksi untuk keberlangsungan usahatani kedelai.Selain itu dalam penyediaan input pertanian, pemerintah turut berperan dalam penyedian benih kedelai dan pupuk bersubsidi dengan memberikan bantuan kepada petani melalui kelompok tani sehingga mampu mencapai produktivitas yang optimal dan turut membantu dalam pengembangan agribisnis kedelai di daerah penelitian.

Keterkaitan antara sub sistem pertanian primer dengan sub sistem hilir dapat dilihat dari aktivitas usahatani dengan aktivitas pengolahan dan pemasaran yang memiliki keterkaitan erat yang saling memberikan manfaat dan keuntungan bagi masing-masing sub sistem. Adapun persentase keterkaitan sub sistem pertanian primer dengan sub sistem hilir adalah kisaran $98 \%$ hal ini dapat dilihat bahwa Aktivitas usahatani kedelai yang dilakukan petani akan menghasilkan sejumlah produksi kedelai dalam bentuk polongan yang memerlukan pengolahan melalui produksi kedelai polongan yang diolah menjadi biji kedelai kering. Sebaliknya pelaku kegiatan pengolahan berperan sebagai pelaku agribisnis yang membutuhkan bahan baku kedelai yang berupa polongan untuk diolah menjadi bentuk biji kering, sehingga dapat memberikan berbagai keuntungan atas pengolahan hasil kedelai yang dilakukan dari kegiatan usahatani kedelai yang menghasilkan produksi kedelai.

Kegiatan pengolahan mampu meningkatkan daya simpan produk, menghasilkan nilai tambah, meningkatkan keterampilan produsen, dan pada akhirnya berperan dalam meningkatkan pendapatan petani kedelai sebagai produsen. Adapun keterkaitan sub sistem pemasaran terhadap sub sistem usahatani (Backward linkage) yaitu sub sistem pemasaran dan distribusi membeli sejumlah biji kedelai yang disediakan petani dengan harga dan kualitas yang telah di sepakati, sedangkan linkage kedepan (Forwad linkage) sub sistem pemasaran yaitu memasarkan dan menyalurkan benih kepada konsumen. Sub sistem pemasaran dan distribusi telah menjalankan peranan dan fungsinya dengan baik karena bisa memberikan manfaat dan keuntungan bagi pelakunya yaitu bisa 
mendapatkan jaminan suplay biji kedelai dari petani dan mendapat laba dari penjualan biji kedelai kepada konsumen.

Lembaga penunjang agribisnis memiliki keterkaitan terhadap suatu sistem agribisnis secara keseluruhan. Hasil penelitian ini memperlihatkan bahwa keterkaitan antara lembaga penunjang dengan sistem agribisnis kedelai di daerah penelitian memiliki keterkaitan yang erat karena keberadaan lembaga penunjang ini akan sangat membantu para pelaku agribisnis pada setiap sub sistem dalam menjalankan peran dan fungsinya masing-masing. Peranan lembaga penunjang sangat diperlukan oleh pelaku agribisnis terutama petani sehingga akan menunjang keberhasilan agribisnis kedelai di daerah penelitian. Lembaga penunjang yang ada di derah penelitian yaitu kelompok tani, Gapoktan, Balai penyuluhan serta pemerintah.

Tabel 1 . Keterkaitan antar Sub Sistem Agribisnis Kedelai Daerah Penelitian

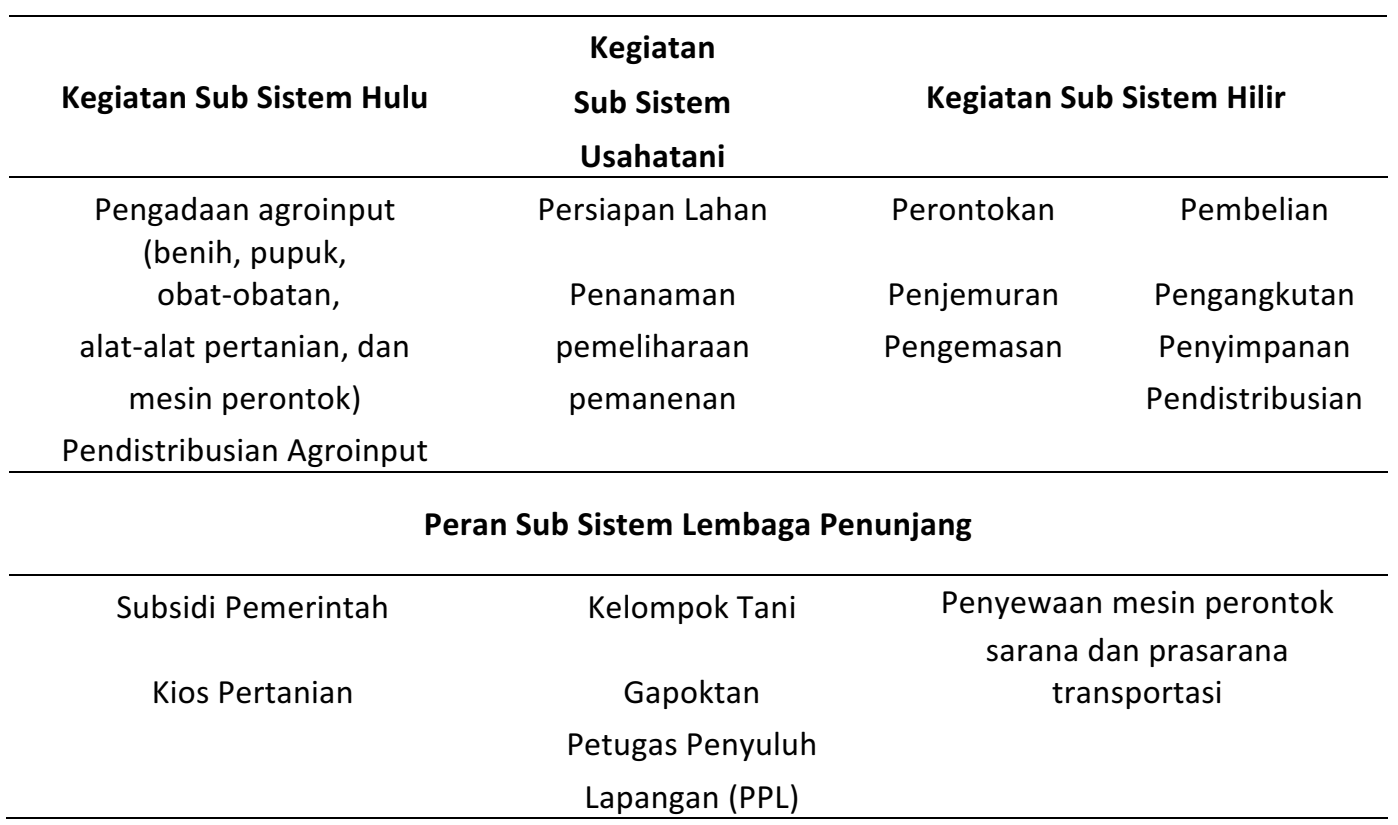

\section{Analisis Biaya Dan Pendapatan Usahatani Kedelai Di Daerah Penelitian}

Biaya produksi kedelai di daerah penelitian adalah biaya yang dikeluarkan untuk membeli benih, pupuk, obat-obatan, membayar upah tenaga kerja, penyusutan peralatan serta membayar biaya perontontokan kedelai.Untuk mendapatkan pendapatan yang maksimal maka petani perlu meningkatkan produksi dan menekan biaya usahatani.Biaya yang dikeluarkan terdiri dari biaya tetap dan biaya variabel.Biaya tetap di daerah penelitian yaitu biaya penyusutan alat sedangkan untuk biaya variabel yaitu biaya benih, biaya pupuk, upah tenaga kerja, obat-obatan dan biaya perontokan biji kedelai (Suratiyah, 2009).

Total biaya yang dikeluarkan petani untuk uasahatani kedelai sampai pengolahan menjadi biji kedelai kering termasuk dalam kategori cukup tinggi dengan biaya yang dikeluarkan petani adalah sebesar Rp34.7038.200,- dengan rata-rata per petani adalah sebesar Rp 5.983.417,24,-. Adapun rincian biaya adalah terdiri dari biaya tetap dan biaya variabel. Rata-rata Jumlah biaya tetap yang di keluarkan petani untuk usahatani kedelai di daerah penelitian adalah sebesar Rp 100510,34 yang terdiri dari penyusutan alat. Sedangkan untuk rata-rata biaya variabel yang dikeluarkan petani di 
daerah penelitian adalah sebesar Rp 5882906.9,- yang terdiri dari biaya benih, upah tenaga kerja, biaya pupuk, biaya obat-obatan dan biaya perontokan.

Tabel 2. Rincian Biaya Pada Usahatani Kedelai Di Daerah Penelitian

\begin{tabular}{|c|c|c|c|}
\hline Jenis Biaya & $\begin{array}{c}\text { Jumlah Satuan } \\
\text { Fisik }\end{array}$ & Biaya (Rp) & Total Biaya (Rp) \\
\hline \multicolumn{4}{|l|}{ A. Biaya Tetap } \\
\hline \multirow[t]{2}{*}{ Penyusutan Peralatan } & & 100510,34 & \\
\hline & Total Biaya Tetap & & 100510,34 \\
\hline \multicolumn{4}{|l|}{ B. Biaya Variabel } \\
\hline 1. Benih & $48,62 \mathrm{Kg}$ & 583448,27 & \\
\hline 2. Upah Tenaga Kerja & $62 \mathrm{HOK}$ & 3738620,69 & \\
\hline \multicolumn{4}{|l|}{ 3. Pupuk } \\
\hline Pupuk Urea & $72,41 \mathrm{Kg}$ & 162206,9 & \\
\hline Pupuk Phonska & $81,03 \mathrm{Kg}$ & 186379,31 & \\
\hline Pupuk SP-36 & $53.33 \mathrm{Kg}$ & 122931,03 & \\
\hline \multicolumn{4}{|l|}{ 4. Obat-obatan } \\
\hline Bio-Up & 6.62 liter & 269310,3 & \\
\hline Bio-Kron & 2.65 liter & 146010,64 & \\
\hline Decis & 0.49 liter & 104462,22 & \\
\hline \multirow[t]{3}{*}{ 5. Biaya perontokan } & $96,32 \mathrm{Kg}$ & 674281,03 & \\
\hline & Total Biaya Variabel & & 5882906,9 \\
\hline & Biaya Total & & 5983417,24 \\
\hline
\end{tabular}

Total biaya yang dikeluarkan petani dalam berusahatani kedelai cukup tinggi. Hal ini diperlukan kebijakan pemerintah yaitu dalam peran pengadaan benih bersubsidi dan pupuk bersubsidi sehingga diharapkan mampu menekan biaya produksi petani yang berpengaruh terhadap pendapatan petani kedelai didaerah penelitian.

Keberhasilan dari suatu usahatani juga dapat dilihat dari pendapatan bersih usahataninya.Pendapatan bersih usahatani berarti mengukur imbalan yang diperoleh petani dari penggunaan faktor-faktor produksi, pengolahan dan modal yang digunakan. Pendapatan yang dimaksud dalam penelitian ini adalah pendapatan bersih yang diterima olah petani dalam satu kali musim tanam. Dimana pendapatan rata-rata petani didaerah penelitian adalah sebesar Rp 5.254.600,-. Besarnya pendapatan petani kedelai di daerah penelitian tergolong cukup tinggi dimana besar kecilnya pendapatan petani di pengaruhi oleh besarnya jumlah produksi yang diperoleh oleh petani.Akan tetapi, petani baru bisa menikmati pendapatan tersebut dalam waktu yang cukup lama sekitar tiga sampai empat bulan sesuai dengan waktu tanam dan pengolahan kedelai sehingga dapat dijual dalam bentuk biji kedelai kering.Pendapatan yang diperoleh petani dari berusahtani kedelai digunakan petani untuk berbagai keperluan diantaranya membeli sejumlah kebutuhan keluarga, membayar hutang, serta sebagian lagi digunakan sebagai modal berusahatani kembali (Soekartawi, 2006). 
Tabel 3. Rata-rata Pendapatan Bersih dan Nilai R/C Pada Usahatani Kedelai Di Daerah Penelitian

\begin{tabular}{ll}
\hline Uraian & Jumlah $(\mathrm{Rp})$ \\
\hline Total Penerimaan (TR) & $11.238 .017,2$ \\
Total Biaya (TC) & 5.983 .417 .24 \\
pendapatan & 5.254 .600 \\
R/C & 1,84 \\
\hline
\end{tabular}

Rata-rata pendapatan bersih petani di daerah penelitian adalah sebesar Rp 5.254.600,- atau setara dengan Rp 4.416.910,14,- per hektar. Pendapatan tersebut di peroleh dari selisih total penerimaan ( $R p$ 11.238.017,2) dengan total biaya ( $R p$ $5.983 .417,24)$. Total biaya di peroleh dari perhitungan total biaya usahatani kedelai di daerah penelitian yang terdiri dari dua komponen biaya yang terdiri dari biaya tetap yaitu penyusutan alat dan biaya variabel yaitu biaya benih, pupuk, obat-obatan, tenaga kerja dan biaya perontokan.Selanjutnya untuk melihat kelayakan usahatani kedelai di daerah penelitian di gunakan di gunakan kriteria investasi yaitu Revenue Cost Ratio $(\mathrm{R} / \mathrm{C})$. Usahatani kedelai didaerah penelitian dapat dikatakan cukup menguntungkan, karena terlihat dari nilai $\mathrm{R} / \mathrm{C}$ sebesar 1,84 . Hal ini menunjukan bahwa setiap rupiah yang diinvestasikan akan memberikan penerimaan sebesar $\mathrm{Rp} 1,84$ atau besarnya keuntungan sebesar Rp 0,84.

\section{KESIMPULAN}

Sistem agribisnis kedelai di daerah penelitian menunjukan kondisi cukup baik, ditandai dengan masing-masing sub sistem agribisnis kedelai di daerah penelitian dimana masing-masing pelaku pada tiap sub sistem menjalankan kegiatan agribisnis sesuai fungsi dan peranannya untuk bisa menjalankan sistem agribisnis kedelai secara menyeluruh. Kinerja agribisnis kedelai di daerah penelitian berjalan cukup baik dan terdapat keterkaitan yang cukup erat antara satu sub sistem dengan sub sistem lain, ditandai dengan masing masing pelaku sub sistem sudah menjalankan peranan dan fungsinya dengan baik serta mendapat keuntungan dan manfaat dari kegiatan usahanya. Serta dari hasil analisis pendapatan usahatani kedelai di daerah penelitian menunjukan bahwa usahatani kedelai yang dilakukan petani memberikan pendapatan yang cukup tinggi dimana memiliki $\mathrm{R} / \mathrm{C}$ sebesar 1,84 . Ini menunjukan bahwa untuk setiap rupiah

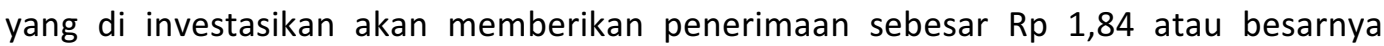
keuntungan sebesar Rp 0,84. Dengan demikian bahwa agribisnis usahatani kedelai di daerah penelitian layak untuk dikembangkan.

\section{UCAPAN TERIMA KASIH}

Pada kesempatan ini penulis ingin menyampaikan terima kasih kepada Camat Berbak, BP3K dan PPL Kecamatan Berbak yang memfasilitasi penelitian di lapangan. 


\section{DAFTAR PUSTAKA}

Dinas Pertanian dan Tanaman Pangan Tanjung Jabung Timur. 2011. Luas Panen, Produksi dan Produktivitas Kedelai Provinsi Jambi 2010. Jambi

2012. Luas Panen, Produksi dan Produktivitas Kedelai Kabupaten Tanjung Jabung Timur tahun 2012. Jambi

Nazir, Moh. 2005. Metode Penelitian. LP3ES. Yogyakarta

Nur dan Sinaga.1995.Cerdas Beragrobisnis. Agromedia Pustaka. Jakarta.

Saragih, B. 2001.Suara dari Bogor : Membangun Sistem Agribisnis. Bogor: Yayasan SESE dan Sucofindo.

Singarimbun dan Sofyan. 1998. Metode Penelitian Survey. LP3ES. Jakarta

Soekartawi. 2006. IImu Usahatani (Definisi Usahatani dan IImu Usahatani). PT Raja Grafindo Persada. Jakarta

Suratiyah, Ken. 2009. Ilmu Usahatani. Penebar Swadaya. Jakarta 